Ömer Halisdemir Üniversitesi İktisadi ve İdari Bilimler Fakültesi Dergisi

Yul: 2021 Cilt-Sayı: 14(1) ss: 46-67

Academic Review of Economics and Administrative Sciences

Year: 2021 Vol-Issue: 14(1) pp: 46-67

http://dergipark.org.tr/tr/pub/ohuiibf/

\title{
Havalimanlarinin Bulanik Dematel Ve Mabac YÖNTEMLERİ İLE SIRALANMASI
}

\author{
Aşkın ÖZDA $\breve{G} O \breve{G L U}$ (D) \\ Murat Kemal KELEŞ ${ }^{\mathbb{D}}{ }^{2}$ \\ Barıș ISSILDAK ${ }^{\text {iD }}$
}

$\ddot{\boldsymbol{O}} \boldsymbol{z}$

Havayolu ulaşımı, diğer ulaşım alternatiflerine göre hızl, güvenilir ve konforlu olduğu için insanlar tarafindan gün geçtikçe daha çok tercih edilmektedir. Ülkemizde havayolu ile ulaşımın yaygınlaşmasına paralel olarak havalimanı sayısında artış olmuş, mevcut havalimanlarının kapasiteleri genişletilmişstir. Havayolu ulaşımına talebin artmasıyla havalimanlarının hizmetleri ve performansları da önemli hale gelmiştir. Bu çalışmada, Türkiye'de aktif olarak faaliyet gösteren 52 adet havalimanının performanslarl Çok Kriterli Karar Verme Yöntemleri kullanılarak değerlendirilmiştir. Çalışmada, Devlet Hava Meydanları İşletmesi Genel Müdürlüğ̈̈'nün havalimanlarına ilişkin 2019 yllına ait verileri analiz edilmiştir. Havalimanlarının performanslarının değerlendirilmesinde; havalimanına inen ve kalkan "toplam uçak sayısı", havalimanını kullanarak seyahat eden "yolcu sayısı", havalimanını kullanan "ticari uçak sayısı", havalimanında işlem gören "Yük" miktarı kriterleri olmak üzere 4 adet kriter baz alınmıştır. Kriterlerin ağırllkları Bulanık DEMATEL yöntemiyle bulunmuş, en önemli kriterin "yolcu saylsı" kriteri olduğu tespit edilmiştir. Havalimanlarının performansları ise MABAC yöntemiyle siralanmıştır. Yapılan siralama sonucunda İstanbul'da faaliyet gösteren havalimanlarının ilk 3 sırada yer aldı̆̆g görülmüş̧ür. Analizler Excel paket programiyla yapılmışstır.

Anahtar Kelimeler $\quad$ : Bulanı DEMATEL, MABAC, Havalimanı Performans, Çok Kriterli Karar Verme Jel Siniflandirilmasi $\quad:$ C44, L93, C02

\footnotetext{
${ }^{1}$ Doç. Dr., Dokuz Eylül Üniversitesi, İşletme Fakültesi İşletme Bölümü, askin.ozdagoglu@deu.edu.tr, ORCID: 0000-0001-5299-0622.

${ }^{2}$ Dr., Isparta Uygulamalı Bilimler Üniversitesi, Keçiborlu MYO, muratkeles@isparta.edu.tr, ORCID: 0000-0003-0374-6839.

${ }^{3}$ Öğr. Gör., Isparta Uygulamalı Bilimler Üniversitesi, Keçiborlu MYO, barisisildak@isparta.edu.tr, ORCID: 0000-0002-2068-1611.
} 


\title{
Sorting Of Airports With Fuzzy Dematel ANd MABAC
}

\begin{abstract}
Airline transportation is preferred more and more by people as it is fast, reliable and comfortable compared to other transportation alternatives. In parallel with the spread of air transportation in our country, the number of airports increased and the capacities of the existing airports were expanded. With the increasing demand for airline transportation, the services and performances of airports have also become important. In this study, 52 of the airport's operating performance active in Turkey were evaluated using Multi-Criteria DecisionMaking methods. In the study, the data of 2019 of the General Directorate of State Airports Authority were analyzed. Four criteria have been taken into consideration for evaluating the performances of airports. These are "total number of aircraft" landing and departing to the airport, "number of passengers traveling using the airport", "number of commercial aircraft" using the airport, "Load" amount processed at the airport. The weights of the criteria were found with the Fuzzy DEMATEL method and it was determined that the most important criterion was the "number of passengers" criterion. The performances of the airports are evaluated by MABAC method. As a result of the ranking made, it is seen that the airports operating in Istanbul are in the top 3. The analyzes were made with the Excel package program.
\end{abstract}

Key Words

Jel Classification
: Fuzzy DEMATEL, MABAC, Airport Performance, Multicriteria Decision Making.

:C44, L93, C02.

\section{GİRIŞ}

Günümüzde küreselleşme ve teknolojinin hızlı gelişimi ile birlikte hız ve zaman faktörü havayolu ulaşımına ve taşımacılığına talebi arttırmıştır. İnsanlar hava yolu ulaşımını genellikle hızlı, güvenli ve rahat olduğu için diğer ulaşım araçlarına göre daha sıklıkla kullanmaktadırlar. Sektördeki firmalar ise, yolculara daha iyi ve daha kaliteli hizmet verebilmek için çalışmalarını sürdürmektedirler.

Havacılık sektörü, ülkelerin ekonomisinin, turizminin, kültürel faaliyetlerinin ve ticaretlerinin gelişimi açısından büyük önem arz etmektedir. Ülkemizde havayolu firmalarının artması ve sefer sayılarının da artmasıyla birlikte sektör daha da gelişmiştir. Havacılık faaliyetlerinin \%10'u havada gerçekleşirken geriye kalan \%90'lık kısmı havalimanlarında gerçekleşmektedir. Ülkemizde havayolu taşımacılığına artan talebi karşılayabilmek adına uçak sayılarının artmasıyla birlikte mevcut havalimanlarının kapasiteleri arttırılmış, yeni havalimanları inşa edilmiştir. Bu nedenle ülkeler, havalimanları yatırımlarına önem vermeye başlamış, bunun sonucunda da havalimanları önemli pazarlar haline gelmiştir (Elgün, Babacan, Kozak, \& Babat, 2013: 70). Günümüzde havacıllk sektörünün öne çıkmasıyla, havalimanlarının performans ve etkinliklerinin dikkate alınarak yeni havalimanlarının plânlanması ve mevcutlar için yeni stratejiler oluşturulması önem arz etmektedir (Avcı \& Aktaş, 2015: 68). Havalimanlarında, yolcuların havalimanına gelişinden uçağa bindikleri ana kadar birçok hizmet sunulmaktadır. Bu süreçte müşterinin sunulan hizmetlerden algıladığ memnuniyet ve memnuniyetsizlikler havalimanının hizmet kalitesini, müşteri memnuniyetini ve sonucunda yolcular tarafindan tercih edilmesini doğrudan etkilemektedir. Dolayısıyla yolculara sunulan hizmetlerin müşteri memnuniyetini ne oranda etkilediği bilinerek gerekli plân ve stratejilerin yapılması havalimanlarının tercih edilmesinde önemli bir adımdır. Havalimanı yönetimleri de havalimanlarını kullanan insanların taleplerini ve ihtiyaçlarını göz önüne alarak önlemler almalıdırlar (Işıldak, 2017: 121).

Devlet Hava Meydanları İşletmesi Genel Müdürlüğü (DHMI)'nün yılsonlarında çıkardığı faaliyet raporlarında belirtildiği gibi, toplumun her kesiminin hava ulaşımına erişimini sağlayabilmek adına ulusal havalimanı sayısında sürekli artış olsa da, fiili duruma bakıldığında bölgeden bölgeye ekonomik yapının farklılaşması, havalimanlarının potansiyelinin de her yerde aynı olmadığı sonucuna ulaştırmaktadır. Dolayısıyla, havalimanlarımızın etkin plânlama, nitelikli 
stratejiler çerçevesinde yenileme ve genişletme çalışmalarına yer verilmesi, tesisleşme yönünde kaliteyi de arttıracaktır. Yalnız bu tesisleşme tek başına yeterli değildir. Müşterinin, hizmeti almadan önce bir beklenti içerisinde olup hizmeti aldıktan sonra gerçekleşen memnuniyet ya da memnuniyetsizliklerinin belirlenmesiyle kalite de gerçekleşmiş olacaktır. Durum böyleyken havalimanı işletmelerinin, müşterilerini memnun edebilmek için kaliteli bir hizmet vermeleri gerekmektedir (Yapraklı \& Sağlık, 2010: 71).

$\mathrm{Bu}$ çerçevede değerlendirme yapıldığında, havayolu ulaşımına talebin artmasına paralel olarak havalimanlarının hizmetleri ve performanslarının önemli hale gelmesi temelinde bu çalışmanın amacı, Türkiye'de aktif olarak faaliyet gösteren 52 adet havalimanının performanslarını değerlendirmektir. Havalimanlarının performanslarının değerlendirilmesinde; havalimanına inen ve kalkan "toplam uçak sayısı", havalimanını kullanarak seyahat eden "yolcu sayısı", havalimanını kullanan "ticari uçak sayısı", havalimanında işlem gören "yük miktarı" kriterleri olmak üzere 4 adet kriter baz alınmıştır. Çalışmada Çok Kriterli Karar Verme (ÇKKV) yöntemlerinden Bulanık DEMATEL ve MABAC kullanılmıştır. Kriterlerin ağırlıkları Bulanık DEMATEL yöntemiyle bulunmuş, havalimanlarının performansları ise MABAC yöntemiyle değerlendirilmiştir. Değerlendirmede DHMİ'nin 2019 yılı verileri baz alınmıştır.

Yapılan literatür incelemesinde havalimanı performanslarının ve etkinliklerinin ölçülmesinde ağırlıklı olarak Veri Zarflama Analizi yönteminin kullanıldığı çalışmalara rastlanmıştır. ÇKKV yöntemlerinin bu konuda kullanıldığı çalışma sayısının az olduğu görülmüştür. Özellikle bu çalışmada kullanılan ÇKKV yöntemlerinden Bulanık DEMATEL ve MABAC yönteminin havalimanı performanslarının sıralanmasında kullanıldığı bir çalışmaya ve buna ilave olarak bu çalışmada kullanılan kriterlerin birlikte kullanıldığı bir çalışmaya rastlanmamıştır. Bu yönleriyle bu çalışmanın literatüre katkı yaptı̆̆ 1 düşünülmektedir.

Çalışmada öncelikle literatür araştırması örnekleri verilmiştir. Daha sonra çalışmada kullanılan ÇKKV yöntemlerinden Bulanık DEMATEL ve MABAC yöntemlerinin algoritması anlatılmıştır. Devam eden aşamada Türkiye'de aktif olarak faaliyet gösteren havalimanlarının performanslarının değerlendirildiği uygulama kısmına ait analizler ve bulgulara yer verilmiştir. Son kısımda sonuç ve öneriler bulunmaktadır.

\section{LITTERATÜR İNCELEMESİ}

Çalışmada kullanılan Bulanık DEMATEL ve MABAC yöntemleriyle yapılan uygulamalardan ve havalimanları ile ilgili çok kriterli karar verme yöntemlerinin kullanıldığı çalışmalardan örneklerin olduğu literatür çalışması Çizelge.1'de gösterilmektedir.

Çizelge 1: Literatür Çalışması

\begin{tabular}{|c|c|c|}
\hline Çalıșmanın yazarı/yazarları & Çalışmanın konusu & Kullanılan yöntem/ler \\
\hline Ayçin \& Çakın (2019) & $\begin{array}{l}\text { AB üyesi ülkelerin inovasyon } \\
\text { performansının ölçülmesi }\end{array}$ & Entropi ve MABAC \\
\hline Bakır (2019) & $\begin{array}{l}\text { Havayolu İşletmelerinde eWOM' } \\
\text { a dayalı memnuniyet düzeyinin } \\
\text { analiz edilmesi }\end{array}$ & SWARA ve MABAC \\
\hline Dash (2019) & $\begin{array}{l}\text { Hindistan havacılık } \\
\text { endüstrisindeki servis } \\
\text { sağlayıcıların performanslarının } \\
\text { karşılaştırılması }\end{array}$ & TOPSIS ve AHP \\
\hline Ersin, Dinçer, \& Yüksel (2019) & $\begin{array}{l}\text { Yerel yönetimlerde yatırım } \\
\text { kriterlerinin değerlendirilmesi }\end{array}$ & Bulanık DEMATEL \\
\hline Koç (2019) & $\begin{array}{l}\text { Tekstil sektöründe uluslararas1 } \\
\text { tedarikçi seçiminde kullanılan } \\
\text { kriterlerin değerlendirilmesi }\end{array}$ & Bulanık DEMATEL \\
\hline $\begin{array}{l}\text { Pishdar, Ghasemzadeh, \& } \\
\text { Antuchevičiené (2019) }\end{array}$ & $\begin{array}{l}\text { İran'daki } 19 \text { havalimanından hub } \\
\text { havalimanı için en uygun olanının } \\
\text { belirlenmesi }\end{array}$ & $\begin{array}{l}\text { Aralık tip } 2 \text { bulanık Best-Worst } \\
\text { Method (BWM) ve MACBETH }\end{array}$ \\
\hline Ulutaş (2019) & $\begin{array}{l}\text { Bir mobilya atölyesi için en uygun } \\
\text { pazarlama yöneticisi belirlenmesi }\end{array}$ & Entropi ve MABAC \\
\hline
\end{tabular}


Özdağoğlu, A., Keleş, M. K., \& Işıldak, B. (2021). Havalimanlarının Bulanık DEMATEL ve MABAC yöntemleri ile sıralanması. Ömer Halisdemir Üniversitesi İktisadi ve İdari Bilimler Fakültesi Dergisi, 14(1), 46-67.

\begin{tabular}{|c|c|c|}
\hline \multicolumn{3}{|c|}{ Çizelge 1: Literatür Çalışması } \\
\hline Çalışmanın yazarı/yazarları & Çalışmanın konusu & Kullanılan yöntem/ler \\
\hline Albayrak \& Erkayman (2018) & Sporcular için akıllı bileklik seçimi & Bulanık DEMATEL ve EDAS \\
\hline Iş1ldak \& Tunca (2018) & $\begin{array}{l}\text { Isparta Süleyman Demirel } \\
\text { Havalimanı kullanan } 500 \text { yolcu } \\
\text { üzerinde uygulanan anket ile } \\
\text { havalimanı hizmetlerinde müşteri } \\
\text { memnuniyetini etkileyen } \\
\text { faktörlerin incelenmesi }\end{array}$ & $\begin{array}{l}\text { Anket, İstatistiki analiz, Faktör } \\
\text { analizi }\end{array}$ \\
\hline Petrovic \& Kankaras (2018) & $\begin{array}{l}\text { Hava trafik koruma uçağının } \\
\text { seçilmesi }\end{array}$ & DEMATEL ve AHP \\
\hline Yu, Wang, \& Wang (2017) & $\begin{array}{l}\text { Trip Advisor web sitesi üzerinden } \\
\text { otel seçimi }\end{array}$ & Bulanık mantık ve MABAC \\
\hline Dao (2016) & $\begin{array}{l}\text { İki havayolu firmasının finansal } \\
\text { oranlar kullanılarak } \\
\text { performanslarının } \\
\text { değerlendirilmesi }\end{array}$ & Oran analizi \\
\hline Altan \& Karaş Aydın (2015) & $\begin{array}{l}\text { Boru üretimi yapan bir işletme için } \\
\text { üçüncü parti lojistik firma seçimi }\end{array}$ & $\begin{array}{l}\text { Bulanık DEMATEL ve BULANIK } \\
\text { TOPSIS }\end{array}$ \\
\hline Avc1 \& Aktaş (2015) & $\begin{array}{l}\text { 2013-2014 yılları için Türkiye'de } \\
\text { faaliyet gösteren havalimanlarının } \\
\text { etkinlik ve verimliliklerinin } \\
\text { ölçülmesi }\end{array}$ & Veri Zarflama Analizi \\
\hline Merkert \& Assaf (2015) & $\begin{array}{l}\text { Algılanan havaalanı kalitesinin } \\
\text { havaalanı kar marjları üzerindeki } \\
\text { etkisinin } 30 \text { uluslararası havaalanı } \\
\text { üzerinde araştırılması. }\end{array}$ & Veri Zarflama Analizi \\
\hline Pamucar \& Cirovic (2015) & $\begin{array}{l}\text { Lojistik merkezleri için forklift } \\
\text { satın alma süreci }\end{array}$ & DEMATEL ve MABAC \\
\hline Ahn \& Min (2014) & $\begin{array}{lr}\text { (2006-2011) } & \text { yılları arasında } \\
\text { uluslararası } & \text { havaalanlarının } \\
\text { karşılaştırmalı } & \text { verimliliklerinin } \\
\text { değerlendirilmesi } & \\
\end{array}$ & $\begin{array}{lll}\text { Veri Zarflama Analizi } & \text { ve } \\
\text { Malmquist Model } & & \\
\end{array}$ \\
\hline Organ (2013) & Tekstil firması için makine seçimi & Bulanık DEMATEL \\
\hline $\operatorname{Ar}(2012)$ & $\begin{array}{l}\text { 2007-2011 dönemi için } \\
\text { Türkiye'deki havalimanlarının } \\
\text { etkinliklerindeki değişimin } \\
\text { incelenmesi }\end{array}$ & $\begin{array}{l}\text { Malmquist-Toplam Faktör } \\
\text { Verimliliği (TFV) Endeksi }\end{array}$ \\
\hline Chang, Chang, \& Wu (2011) & $\begin{array}{ll}\begin{array}{l}\text { Elektronik } \\
\text { tedarikçi seçimi }\end{array} & \text { endüstrisindeki } \\
\end{array}$ & Bulanık DEMATEL \\
\hline Gökdalay \& Evren (2009) & $\begin{array}{l}\text { Ulusal ve uluslararası } \\
\text { havaalanlarının performans analizi } \\
\text { ve karşılaştırılması }\end{array}$ & $\begin{array}{l}\text { Bulanık TOPSIS ve Bulanık Basit } \\
\text { Ağırlıklı Toplam }\end{array}$ \\
\hline Shyr \& Kuo (2008) & $\begin{array}{l}\text { Havayollarında birleştirme } \\
\text { faktörlerinin değerlendirilmesi }\end{array}$ & TOPSIS ve Oyun teorisi \\
\hline $\begin{array}{l}\text { Veskovic, Stević, Stojić, } \\
\text { Vasiljević, \& Milinković (2008) }\end{array}$ & $\begin{array}{lr}\text { Bosna-Hersek'te } & \text { demiryolu } \\
\text { taşımac1lığ } & \text { yönetiminin } \\
\text { değerlendirilmesi } & \end{array}$ & Delphi, SWARA ve MABAC \\
\hline Ling, Lin, \& Lu (2005) & $\begin{array}{l}\text { Çin-Tayvan arası hava yolculuğu } \\
\text { yapan } 404 \text { yolcunun, havayolu } \\
\text { şirketinin hizmet kalitesi ile } \\
\text { müşteri memnuniyeti arasındaki } \\
\text { ilişkinin değerlendirilmesi }\end{array}$ & SERVQUAL model \\
\hline
\end{tabular}

\section{II.MABAC}

MABAC (Multi-Attributive Border Approximation Area Comparison) yöntemi değerlendirmede dikkate alınan kriterlerin sınır yakınlık alanına uzaklıklarını hesaplamaya dayanan bir çok kriterli karar verme yöntemidir. MABAC yönteminin hesaplama süreci aşağıdaki gibi gösterilebilir (Bakır, 2019: 55-57; Gigovic, Pamucar, Bozanic, \& Ljubojevic, 2017: 509-512).

MABAC yöntemine göre ilk olarak karar matrisi oluşturulmalıdır. Karar matrisinin yapısı Eşitlik 1'de gösterilmiştir. 


$$
\begin{gathered}
\text { i:alternatif } ; i=1,2,3, \ldots, m \\
{\left[\begin{array}{cccc}
x_{11} & x_{12} & \ldots & x_{1 n} \\
x_{21} & x_{22} & \ldots & x_{2 n} \\
\ldots & \ldots & \ldots & \ldots \\
x_{m 1} & x_{m 2} & \ldots & x_{m n}
\end{array}\right]}
\end{gathered}
$$

MABAC yönteminde bir sonraki adım karar matrisindeki değerlerin normalize edilmesidir. Fayda kriterleri için normalizasyon işlemi Eşitlik 2 kullanılarak gerçekleştirilir.

$$
\begin{aligned}
& n_{i j}: \text { i. alternatifin } j . \text { kriter açısından sahip olduğu normalize değer } \\
& n_{i j}= \frac{x_{i j}-\min _{j} x_{i j}}{\max _{j} x_{i j}-\min _{j} x_{i j}} \\
& \text { Eşitlik } 2
\end{aligned}
$$

Maliyet kriterleri için normalizasyon işlemi Eşitlik 3 kullanılarak gerçekleştirilir.

$$
n_{i j}=\frac{x_{i j}-\max _{j} x_{i j}}{\min _{j} x_{i j}-\max _{j} x_{i j}}
$$

Ardından Eşitlik 4'e göre ağırlıklı normalize karar matrisi hazırlanır.

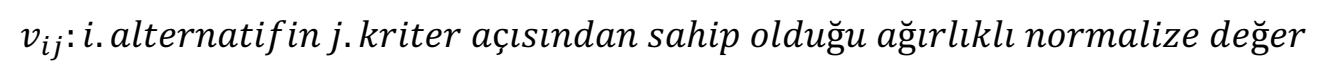

$$
v_{i j}=w_{j}\left(n_{i j}+1\right) \quad \text { Eşitlik } 4
$$

İzleyen adımda her bir kriter için sınır yakınlık değeri belirlenmelidir. Sınır yakınlık değerleri Eşitlik 5 kullanılarak hesaplanır.

$$
g_{j}: j . \text { kriterin sınır yakınlık değeri }
$$

$$
g_{j}=\sqrt[m]{\prod_{i=1}^{m} v_{i j}} \forall j i c ̧ i n \quad \text { Eşitlik } 5
$$

Daha sonra ağırlıklı normalize karar matrisindeki değerlerin sınır yakınlık alanından uzaklıkları Eşitlik 6 yardımıyla hesaplanır.

$$
\begin{aligned}
& q_{i j}: i . \text { alternatifin } j . \text { kriter açısından sınır yakınlık alanına uzaklığı } \\
& q_{i j}=v_{i j}-g_{j} \quad \text { Eşitlik } 6
\end{aligned}
$$

Son işlem olarak alternatiflerin sınır yakınlık alanından uzaklıklarının toplamı Eşitlik 7 kullanılarak hesaplanır.

$$
S_{i}: \text { i.alternatifin sınır yakınlık alanına uzaklığ }
$$

$$
\begin{array}{ll}
S_{i}=\sum_{j=1}^{n} q_{i j} & \text { Eşitlik } 7
\end{array}
$$

Eşitlik 7'ye göre elde edilen değerlerin en büyügü karar verme problemindeki en iyi alternatifi göstermektedir.

\section{III.BULANIK DEMATEL}

Bulanık DEMATEL (Decision-Making Trial and Evaluation Laboratory) karar verme probleminde yer alan kriterler arasındaki etkileşimleri göz önüne alarak kriter ağırlıklarını bulan bir yöntemdir. Yöntemin işleyişi aşağıda gösterilmiştir (Altan \& Karaş Aydın, 2015, 103-105).

İlk aşamada, kriterler arasındaki etkileşimler uzmanlar tarafından değerlendirilir. Bunun için kullanılan dilsel ifadeler ve üçgen bulanık sayı karşı1ıkları Tablo 1'de verilmiştir. 
Tablo 1: Bulanık DEMATEL Ölçeği

\begin{tabular}{|c|c|}
\hline Dilsel İfade & Üçen Bulanık Sayı \\
\hline İki kriter arasında hiç etkileşim yok & 0,$00 ; 0,00 ; 0,00$ \\
\hline İki kriter arasında çok az etkileşim var & 0,$00 ; 0,00 ; 0,25$ \\
\hline İki kriter arasında az etkileşim var & 0,$00 ; 0,25 ; 0,50$ \\
\hline İki kriter arasında normal etkileşim var & 0,$25 ; 0,50 ; 0,75$ \\
\hline İki kriter arasında fazla etkileşim var & 0,$50 ; 0,75 ; 1,00$ \\
\hline İki kriter arasında çok fazla etkileşim var & 0,$75 ; 1,00 ; 1,00$ \\
\hline
\end{tabular}

$i, j:$ kriter $; i=1,2,3, \ldots, n ; j=1,2,3, \ldots, n$

$K$ : karar verici; $K=1,2,3, \ldots, k$

$l_{i j K}: K$. karar vericinin i. kriterin j. kriter üzerindeki etkisine ilişkin görüșü

alt limit değeri

$m_{i j K}:$ K. karar vericinin i. kriterin j. kriter üzerindeki etkisine ilişkin görüşü

üyelik derecesinin 1 olduğu nokta

$u_{i j K}:$ K. karar vericinin i. kriterin j. kriter üzerindeki etkisine ilişkin görüşü

üst limit değeri

$\tilde{d}_{i j K}:$ K. karar vericinin i. kriterin j. kriter üzerindeki etkisine ilişkin görüşünden oluşan üçgen bulanık sayı

Uzman tarafından satırdaki kriterin sütundaki kriter üzerindeki etkisini gösteren üçgen bulanık sayı Eşitlik 8'deki gibi gösterilebilir.

$$
d_{i j K}=l_{i j K} ; m_{i j K} ; u_{i j K}
$$

Eşitlik 8

$\mathrm{Bu}$ uzman görüşleri o uzmana ilişkin bulanık başlangıç direkt ilişki matrisini oluşturur. Bulanık başlangıç direkt ilişki matrisinin yapısı Eşitlik 9'da gösterilmiştir.

$$
\begin{aligned}
& \widetilde{D_{K}}: \text { K. karar vericinin bulanık bașlangıç direkt ilişki matrisi } \\
& \widetilde{D}_{K}=\left[\begin{array}{llll}
\tilde{d}_{11 K} & \tilde{d}_{12 K} & \ldots & \tilde{d}_{1 n K} \\
\tilde{d}_{21 K} & \tilde{d}_{22 K} & \ldots & \tilde{d}_{2 n K} \\
\ldots & \ldots & \ldots & \ldots \\
\tilde{d}_{n 1 K} & \tilde{d}_{n 2 K} & \ldots & \tilde{d}_{n n K}
\end{array}\right]
\end{aligned}
$$

İzleyen adımda uzman görüşleri birleştirilerek tek bir bulanık başlangıç direkt ilişki matrisi oluşturulur.

$l_{i j}: i$. kriterin j. kriter üzerindeki etkisine ilişsin birleștirilmiş alt limit değeri

$m_{i j}:$ i. kriterin j. kriter üzerindeki etkisine ilişkin birleştirilmiş

üyelik derecesinin 1 olduğu nokta

$u_{i j}: i$. kriterin j. kriter üzerindeki etkisine ilişkin birleștirilmiş üst limit değeri

$\tilde{d}_{i j}: i$. kriterin j. kriter üzerindeki etkisine ilişkin birleştirilmiş üçgen bulanık sayı

Birleştirme işlemleri Eşitlik 10, 11 ve 12'de gösterilmiştir.

$$
\begin{array}{ll}
l_{i j}=\frac{\sum_{K=1}^{k} l_{i j K}}{k} & \text { Eşitlik 10 } \\
m_{i j}=\frac{\sum_{K=1}^{k} m_{i j K}}{k} & \text { Eşitlik 11 } \\
u_{i j}=\frac{\sum_{K=1}^{k} u_{i j K}}{k} & \text { Eşitlik 12 }
\end{array}
$$


Elde edilen bulanık başlangıç direkt ilişki matrisi Eşitlik 13’teki gibi oluşur.

$$
\widetilde{D}_{K}=\left[\begin{array}{cccc}
\tilde{d}_{11} & \tilde{d}_{12} & \ldots & \tilde{d}_{1 n} \\
\tilde{d}_{21} & \tilde{d}_{22} & \ldots & \tilde{d}_{2 n} \\
\ldots & \ldots & \ldots & \ldots \\
\tilde{d}_{n 1} & \tilde{d}_{n 2} & \ldots & \tilde{d}_{n n}
\end{array}\right]
$$

İzleyen adımda, normalize direkt ilişki matrisi hazırlanır. Normalizasyon işlemi için uygulanması gereken adımlar Eşitlik 14, 15 ve 16' da verilmiştir.

$\tilde{x}_{i j}: i$. kriterin j. kriter üzerindeki etkisine ilişkin normalize

üçgen bulanık sayı

$$
\begin{aligned}
& \sum_{j=1}^{n} u_{i j}, \forall i \text { için } \\
& \sum_{i=1}^{n} u_{i j}, \forall j i c ̧ i n
\end{aligned}
$$

$\tilde{x}_{i j}=\frac{l_{i j}}{\max \left\{\sum_{j=1}^{n} u_{i j}, \forall i \text { için; } \sum_{i=1}^{n} u_{i j}, \forall j i c ̧ i n\right\}}$;

$\frac{m_{i j}}{\max \left\{\sum_{j=1}^{n} u_{i j}, \forall i \text { için; } \sum_{i=1}^{n} u_{i j}, \forall j i c ̧ i n\right\}}$;

$\left.\frac{u_{i j}}{\max \left\{\sum_{j=1}^{n} u_{i j}, \forall i \text { için; } \sum_{i=1}^{n} u_{i j}, \forall j i c ̧ i n\right\}}\right\}$

Eşitlik 16

Bu işlemler sonucunda elde edilen normalize direkt ilişki matrisi Eşitlik 17'de gösterilmiştir.

$$
\tilde{X}=\left[\begin{array}{cccc}
\tilde{x}_{11} & \tilde{x}_{12} & \ldots & \tilde{x}_{1 n} \\
\tilde{x}_{21} & \tilde{x}_{22} & \ldots & \tilde{x}_{2 n} \\
\ldots & \ldots & \ldots & \ldots \\
\tilde{x}_{n 1} & \tilde{x}_{n 2} & \ldots & \tilde{x}_{n n}
\end{array}\right]
$$

Ardından bulanık toplam ilişki matrisi Eşitlik 18 yardımıyla hesaplanır.

\section{T: bulanık toplam ilișki matrisi}

\section{I: birim matris}

$$
\tilde{T}=\frac{\tilde{X}}{I-\tilde{X}}
$$

Buna göre bulanık toplam ilişki matrisi Eşitlik 19'daki gibi oluşur.

$\tilde{t}_{i j}:$ i. kriterin j. kriter üzerindeki etkisine ilișkin

bulanık toplam iliş̧ki matrisi değeri

$$
\widetilde{T}=\left[\begin{array}{cccc}
\tilde{t}_{11} & \tilde{t}_{12} & \ldots & \tilde{t}_{1 n} \\
\tilde{t}_{21} & \tilde{t}_{22} & \ldots & \tilde{t}_{2 n} \\
\ldots & \ldots & \ldots & \ldots \\
\tilde{t}_{n 1} & \tilde{t}_{n 2} & \ldots & \tilde{t}_{n n}
\end{array}\right]
$$

Daha sonra bulanık toplam ilişki matrisindeki satır ve sütun toplamlanı bulunur. Satır toplamları Eşitlik 20, sütun toplamları Eşitlik 21 kullanılarak hesaplanır.

$\widetilde{R}_{i}:$ i. kriter için satır toplamı

$\tilde{C}_{i}:$ i. kriter için sütun toplamı

$$
\begin{aligned}
& \tilde{R}_{i}=\sum_{j=1}^{n} \tilde{t}_{i j}, \forall i \text { için } \\
& \tilde{C}_{i}=\sum_{i=1}^{n} \tilde{t}_{j i}, \forall i \text { için }
\end{aligned}
$$$$
\text { Eşitlik } 20
$$ 
$a_{i}:$ i. kritere ilişkin $\widetilde{R}_{i}$ bulanık sayısı alt limit değeri

$b_{i}:$ i. kritere ilişkin $\tilde{R}_{i}$ bulanık sayısı orta değeri

$c_{i}:$ i. kritere ilișkin $\tilde{R}_{i}$ bulanık sayısı üst limit değeri

$d_{i}:$ i. kritere ilişkin $\tilde{C}_{i}$ bulanık sayısı alt limit değeri

$e_{i}:$ i. kritere ilişkin $\tilde{C}_{i}$ bulanık sayısı orta değeri

$f_{i}:$ i. kritere ilişkin $\tilde{C}_{i}$ bulanık sayısı üst limit değeri

Eşitlik 20 ve 21 'deki değerlerin toplamları ve farkları alınarak her bir kriter için etkileme ve etkilenme dereceleri saptanır.

$$
\begin{aligned}
\tilde{R}_{i}+\tilde{C}_{i} & =\left\{a_{i}+d_{i} ; b_{i}+e_{i} ; c_{i}+f_{i}\right\} & & \text { Eşitlik 22 } \\
\tilde{R}_{i}-\tilde{C}_{i} & =\left\{a_{i}-f_{i} ; b_{i}-e_{i} ; c_{i}-d_{i}\right\} & & \text { Eşitlik 23 }
\end{aligned}
$$

Bunun ardından üçgen bulanık sayıyı oluşturan değerlerin ortalaması alınarak durulaştırma işlemi gerçekleştirilir. Durulaştırma işlemleri Eşitlik 24 ve 25 'te gösterilmiştir.

$$
\begin{array}{ll}
R_{i}+C_{i}=\frac{a_{i}+d_{i}+b_{i}+e_{i}+c_{i}+f_{i}}{3} & \text { Eşitlik 24 } \\
R_{i}-C_{i}=\frac{\left(a_{i}-f_{i}\right)+\left(b_{i}-e_{i}\right)+\left(c_{i}-d_{i}\right)}{3} & \text { Eşitlik 25 }
\end{array}
$$

Durulaştırılan bu değerler yardımıyla normalize edilmemiş kriter ağırlıkları bulunur. Normalize edilmemiş kriter ağırlıkları bulunması Eşitlik 26'da gösterilmiştir.

$n w_{i}:$ i. kriterin normalize edilmemiş ă̆ $\mathrm{lrl} l k$ değeri

$$
n w_{i}=\sqrt{\left(R_{i}+C_{i}\right)^{2}+\left(R_{i}-C_{i}\right)^{2}} \quad \text { Eşitlik } 26
$$

Son olarak ağırlık değerleri Eşitlik 27 yardımıyla normalize edilir. Normalizasyon işlemi sonrasında kriterlerin ağırlık değerlerinin toplamı 1'e eşittir.

$w_{i}:$ i. kriterin normalize edilmiş ağırlık değeri

$$
w_{i}=\frac{n w_{i}}{\sum_{i=1}^{n} n w_{i}} ; \forall i \text { için } \quad \text { Eşitlik } 27
$$

$\mathrm{Bu}$ değerler içerisindeki en büyük değer karar verme probleminde dikkate alınması gereken en önemli kriteri ifade etmektedir.

\section{UYGULAMA}

Uygulama kapsamında öncelikle havalimanlarını değerlendirmede dikkate alınması gereken kriterlerin ağırlıkları tespit edilmiştir. Kriter numaraları, isimleri ve tipleri Tablo 2'de gösterilmiştir.

Tablo 2: Kriter Kodları ve Adları

\begin{tabular}{|c|c|c|c|}
\hline Kriter Kodu & Kriter Türü & Kriter Adı & Ölçüm Birimi \\
\hline K1 & Fayda yönlü & Tüm Uçak & İniş-Kalkış \\
\hline K2 & Fayda yönlü & Yolcu & Adet \\
\hline K3 & Fayda yönlü & Ticari Uçak & İniş-Kalkış \\
\hline K4 & Fayda yönlü & Yük & Ton \\
\hline
\end{tabular}

\section{Kriterlerin Tanımlanması}

Çalışmada kullanılan değerlendirme kriterlerine ait açıklamalar şu şekildedir (Havalimanı İstatistikleri Metaveri Dosyas1, 2016:1, Erişim Tarihi:29.02.2020):

- Toplam uçak: Havalimanına iniş, kalkış yapan uçak trafiğgine denir. İniş ve kalkışlar iki eylem olarak sayılır. 
- Yolcu: Havayolu firmasıyla seyahat eden uçuş personeli ve kabin ekibi dışında kalanlardır.

- Ticari uçak: Ücret karş1lığ1 plânlanan uçuşlara denir.

- Yük: Bagaj, kargo ve posta miktarlarının toplamıdır.

$\checkmark$ Bagaj: Havayolu tarafından uçakta taşınan ya da uçağa yüklenen uçuş personeli, kabin ekibi ve yolcuların kişisel eşyalarıdır

$\checkmark$ Kargo: Yolcu bagajları haricinde uçakta taşınan eşyalardır. Kargolar; koli ve diplomatik çantaları içermektedir.

$\checkmark$ Posta: Havayolu tarafından taşınan yazışmaları, evrakları ve diğer nesneleri kapsamaktadır.

Tablo 2'deki kriterlere ilişkin olarak havalimanlarına iniş yapan uçak sayısı, kalkış yapan uçak sayısı gibi detay bilgiler mevcuttur. Ancak havalimanı performansını değerlendirmede toplam say1 dikkate alındığından dolayı uzman görüşleri doğrultusunda bunlar farklı kriterler olarak ele alınmayıp birleştirilmiştir. Tablo 2'deki kriterlerin ağılıklarını tespit etmek amacıyla bir form hazırlanarak dört uzmandan görüş alınmıştır. Bu uzman ekibi; ulaştırma hizmetleri bölümü, sivil havacılık kabin hizmetleri programı öğretim elemanı, Isparta Süleyman Demirel Havalimanı harekat memuru ve Isparta Süleyman Demirel Havalimanı bilet satış görevlisinden oluşmaktadır. Uzmanların verdikleri cevaplar doğrultusunda dört farklı bulanık başlangıç direkt ilişki matrisi oluşmuştur. Bu matrislerden biri örnek olarak verilmiştir. Tablo 3 örnek bulanık başlangıç direkt ilişki matrisi alt limit değerlerini, Tablo 4 örnek bulanık başlangıç direkt ilişki matrisi orta değerlerini ve Tablo 5 örnek bulanık başlangıç direkt ilişki matrisi üst limit değerlerini göstermektedir.

Tablo 3: Örnek Bulanık Başlangıç Direkt İlişki Matrisi Alt Limit Değerleri

\begin{tabular}{|c|c|c|c|c|}
\hline & K1 & K2 & K3 & K4 \\
\hline K1 & 0,000000 & 0,250000 & 0,000000 & 0,250000 \\
\hline K2 & 0,250000 & 0,000000 & 0,750000 & 0,750000 \\
\hline K3 & 0,000000 & 0,500000 & 0,000000 & 0,500000 \\
\hline
\end{tabular}

Tablo 4: Örnek Bulanık Başlangıç Direkt İlişsi Matrisi Orta Değerleri

\begin{tabular}{|c|c|c|c|c|}
\hline & K1 & K2 & K3 & K4 \\
\hline K1 & 0,000000 & 0,500000 & 0,250000 & 0,500000 \\
\hline K2 & 0,500000 & 0,000000 & 1,000000 & 1,000000 \\
\hline K3 & 0,250000 & 0,750000 & 0,000000 & 0,750000 \\
\hline
\end{tabular}

Tablo 5: Örnek Bulanık Başlangıç Direkt İlişki Matrisi Üst Limit Değerleri

\begin{tabular}{|c|c|c|c|c|}
\hline & $\mathrm{K} 1$ & $\mathrm{~K} 2$ & $\mathrm{~K} 3$ & $\mathrm{~K} 4$ \\
\hline $\mathrm{K} 1$ & 0,000000 & 0,750000 & 0,500000 & 0,750000 \\
\hline $\mathrm{K} 2$ & 0,750000 & 0,000000 & 1,000000 & 1,000000 \\
\hline K3 & 0,500000 & 1,000000 & 0,000000 & 1,000000 \\
\hline $\mathrm{K} 4$ & 1,000000 & 1,000000 & 1,000000 & 0,000000 \\
\hline
\end{tabular}

Daha sonra Eşitlik 10, 11 ve 12 kullanılarak uzman görüşleri birleştirilmiştir. Tablo 6 birleştirilmiş bulanık başlangıç direkt ilişki matrisi alt limit değerlerini, Tablo 7 birleştirilmiş bulanık başlangıç direkt ilişki matrisi orta değerlerini ve Tablo 8 birleştirilmiş bulanık başlangıç direkt ilişki matrisi üst limit değerlerini göstermektedir.

Tablo 6: Birleştirilmiş Bulanık Başlangıç Direkt İliş̧i Matrisi Alt Limit Değerleri

\begin{tabular}{|c|c|c|c|c|}
\hline & K1 & K2 & K3 & K4 \\
\hline K1 & 0,000000 & 0,375000 & 0,125000 & 0,125000 \\
\hline K2 & 0,375000 & 0,000000 & 0,750000 & 0,750000 \\
\hline K3 & 0,125000 & 0,625000 & 0,000000 & 0,562500 \\
\hline
\end{tabular}

Tablo 7: Birleştirilmiş Bulanık Başlangıç Direkt İlişki Matrisi Orta Değerleri

\begin{tabular}{|c|c|c|c|c|}
\hline & K1 & K2 & K3 & K4 \\
\hline K1 & 0,000000 & 0,625000 & 0,375000 & 0,375000 \\
\hline K2 & 0,625000 & 0,000000 & 1,000000 & 1,000000 \\
\hline K3 & 0,375000 & 0,875000 & 0,000000 & 0,812500 \\
\hline K4 & 0,750000 & 0,625000 & 0,750000 & 0,000000 \\
\hline
\end{tabular}


Özdağoğlu, A., Keleş, M. K., \& Işıldak, B. (2021). Havalimanlarının Bulanık DEMATEL ve MABAC yöntemleri ile sıralanması. Ömer Halisdemir Üniversitesi İktisadi ve İdari Bilimler Fakültesi Dergisi, 14(1), 46-67.

Tablo 8: Birleştirilmiş Bulanık Başlangıç Direkt İlişsi Matrisi Üst Limit Değerleri

\begin{tabular}{|c|c|c|c|c|}
\hline & K1 & K2 & K3 & K4 \\
\hline K1 & 0,000000 & 0,875000 & 0,625000 & 0,625000 \\
\hline K2 & 0,875000 & 0,000000 & 1,000000 & 1,000000 \\
\hline K3 & 0,625000 & 1,000000 & 0,000000 & 1,000000 \\
\hline K4 & 1,000000 & 0,875000 & 1,000000 & 0,000000 \\
\hline
\end{tabular}

İzleyen adımda, Eşitlik 14, 15 ve 16 yardımıyla normalize direkt ilişki matrisi hazırlanmıştır. Tablo 9 normalize direkt ilişki matrisi alt limit değerlerini, Tablo 10 normalize direkt ilişki matrisi orta değerlerini ve Tablo 11 normalize direkt ilişki matrisi üst limit değerlerini göstermektedir.

Tablo 9: Normalize Direkt İlișki Matrisi Alt Limit Değerleri

\begin{tabular}{|c|c|c|c|c|}
\hline & K1 & K2 & K3 & K4 \\
\hline K1 & 0,000000 & 0,130435 & 0,043478 & 0,043478 \\
\hline K2 & 0,130435 & 0,000000 & 0,260870 & 0,260870 \\
\hline K3 & 0,043478 & 0,217391 & 0,000000 & 0,195652 \\
\hline K4 & 0,173913 & 0,130435 & 0,173913 & 0,000000 \\
\hline
\end{tabular}

Tablo 10: Normalize Direkt İlişski Matrisi Orta Değerleri

\begin{tabular}{|c|c|c|c|c|}
\hline & K1 & K2 & K3 & K4 \\
\hline K1 & 0,000000 & 0,217391 & 0,130435 & 0,130435 \\
\hline K2 & 0,217391 & 0,000000 & 0,347826 & 0,347826 \\
\hline K3 & 0,130435 & 0,304348 & 0,000000 & 0,282609 \\
\hline K4 & 0,260870 & 0,217391 & 0,260870 & 0,000000 \\
\hline
\end{tabular}

Tablo 11: Normalize Direkt İlişsi Matrisi Üst Limit Değerleri

\begin{tabular}{|c|c|c|c|c|}
\hline & K1 & K2 & K3 & K4 \\
\hline K1 & 0,000000 & 0,304348 & 0,217391 & 0,217391 \\
\hline K2 & 0,304348 & 0,000000 & 0,347826 & 0,347826 \\
\hline K3 & 0,217391 & 0,347826 & 0,000000 & 0,347826 \\
\hline K4 & 0,347826 & 0,304348 & 0,347826 & 0,000000 \\
\hline
\end{tabular}

Ardından bulanık toplam ilişki matrisi Eşitlik 18 yardımıyla hesaplanmıştır. Tablo 12 bulanık toplam ilişki matrisi alt limit değerlerini, Tablo 13 bulanık toplam ilişki matrisi orta değerlerini ve Tablo 14 bulanık toplam ilişki matrisi üst limit değerlerini göstermektedir.

Tablo 12: Bulanık Toplam İlişki Matrisi Alt Limit Değerleri

\begin{tabular}{|c|c|c|c|c|}
\hline & K1 & K2 & K3 & K4 \\
\hline K1 & 0,047371 & 0,175481 & 0,110972 & 0,113027 \\
\hline K2 & 0,236079 & 0,164458 & 0,381637 & 0,388704 \\
\hline K3 & 0,143402 & 0,306903 & 0,140098 & 0,309359 \\
\hline K4 & 0,237884 & 0,235779 & 0,267356 & 0,124159 \\
\hline
\end{tabular}

Tablo 13: Bulanık Toplam İlișki Matrisi Orta Değerleri

\begin{tabular}{|c|c|c|c|c|}
\hline & K1 & K2 & K3 & K4 \\
\hline K1 & 0,311811 & 0,542559 & 0,489799 & 0,498243 \\
\hline K2 & 0,706884 & 0,623571 & 0,894219 & 0,909637 \\
\hline K3 & 0,568281 & 0,760729 & 0,540673 & 0,774133 \\
\hline K4 & 0,644129 & 0,692939 & 0,724084 & 0,529671 \\
\hline
\end{tabular}

Tablo 14: Bulanık Toplam İlișki Matrisi Üst Limit Değerleri

\begin{tabular}{|c|c|c|c|c|}
\hline & K1 & K2 & K3 & K4 \\
\hline K1 & 2,058511 & 2,446809 & 2,324468 & 2,324468 \\
\hline K2 & 2,841017 & 2,806147 & 2,976950 & 2,976950 \\
\hline K3 & 2,643693 & 2,906352 & 2,568920 & 2,826985 \\
\hline K4 & 2,848032 & 3,020361 & 2,955903 & 2,697838 \\
\hline
\end{tabular}

Bulanık toplam ilişki matrisine Eşitlik 20'deki işlemlerin uygulanması sonucu bulunan değerler Tablo 15'tedir. 
Özdağoğlu, A., Keleş, M. K., \& Işıldak, B. (2021). Havalimanlarının Bulanık DEMATEL ve MABAC yöntemleri ile sıralanması. Ömer Halisdemir Üniversitesi İktisadi ve İdari Bilimler Fakültesi Dergisi, 14(1), 46-67.

Tablo 15: $\widetilde{R}_{i}$ Değerleri

\begin{tabular}{|c|c|c|c|}
\hline K1 & 0,446851 & 1,842412 & 9,154255 \\
\hline K2 & 1,170878 & 3,134312 & 11,601064 \\
\hline K3 & 0,899763 & 2,643816 & 10,945951 \\
\hline K4 & 0,865178 & 2,590823 & 11,522135 \\
\hline
\end{tabular}

Bulanık toplam ilişki matrisine Eşitlik 21'deki işlemlerin uygulanması sonucu bulunan değerler Tablo 16'dadır.

Tablo 16: $\widetilde{C}_{i}$ Değerleri

\begin{tabular}{|l|l|l|l|}
\hline K1 & 0,664736 & 2,231105 & 10,391253 \\
\hline K2 & 0,882621 & 2,619799 & 11,179669 \\
\hline K3 & 0,900063 & 2,648774 & 10,826241 \\
\hline K4 & 0,935250 & 2,711684 & 10,826241 \\
\hline
\end{tabular}

Eşitlik 22'deki işlemlerin uygulanması sonucu bulunan değerler Tablo 17'dedir.

Tablo 17: $\widetilde{R}_{i}+\widetilde{\boldsymbol{C}}_{i}$ Değerleri

\begin{tabular}{|l|l|l|l|}
\hline K1 & 1,111587 & 4,073517 & 19,545508 \\
\hline K2 & 2,053499 & 5,754110 & 22,780733 \\
\hline K3 & 1,799826 & 5,292590 & 21,772192 \\
\hline K4 & 1,800428 & 5,302507 & 22,348376 \\
\hline
\end{tabular}

Eşitlik 23'teki işlemlerin uygulanması sonucu bulunan değerler Tablo 18'dedir.

Tablo 18: $\widetilde{\boldsymbol{R}}_{\boldsymbol{i}}-\widetilde{\boldsymbol{C}}_{\boldsymbol{i}}$ Değerleri

\begin{tabular}{|c|c|c|c|}
\hline K1 & $-9,944402$ & $-0,388693$ & 8,489519 \\
\hline K2 & $-10,008791$ & 0,514513 & 10,718443 \\
\hline K3 & $-9,926478$ & $-0,004958$ & 10,045887 \\
\hline K4 & $-9,961063$ & $-0,120861$ & 10,586885 \\
\hline
\end{tabular}

Durulaştırma işlemlerinin sonuçları ile normalize edilmemiş ve normalize edilmiş ağırlıklar Tablo 19'da gösterilmiştir.

Tablo 19: Durulaştırma İşlemleri ve Ağırlıklar

\begin{tabular}{|c|c|c|c|c|}
\hline & $R_{i}+C_{i}$ & $R_{i}-C_{i}$ & $n w_{i}$ & $w_{i}$ \\
\hline $\mathrm{K} 1$ & 8,243537 & $-0,614525$ & 8,266411 & 0,218049 \\
\hline $\mathrm{K} 2$ & 10,196114 & 0,408055 & 10,204276 & 0,269165 \\
\hline $\mathrm{K} 3$ & 9,621536 & 0,038150 & 9,621612 & 0,253796 \\
\hline $\mathrm{K} 4$ & 9,817103 & 0,168320 & 9,818546 & 0,258990 \\
\hline
\end{tabular}

Bu değerleri açıklamak gerekirse, uzman görüşüne göre bir havalimanını değerlendirmede en önemli kriter yolcu sayısı en önemsiz kriter ise iniş kalkış yapan uçakların sayısıdır.

Kriter ağırlıklarının belirlenmesinin ardından Türkiye'deki havalimanlarının değerlendirmesi yapılmıştır. Bunun için yukarıda belirtilen kriterler dikkate alınmıştır. Söz konusu kriterlerin ölçüm birimleri ise birbirinden farklıdır. Ancak yeni çok kriterli karar verme yöntemlerinden biri olan MABAC açısından bu bir kısıt oluşturmamaktadır. Yapılan normalizasyon işlemi ölçüm birimleri birbirinden farklı olan kriterlerin bir arada değerlendirilmesine olanak sağlamaktadır. Ayrıca yeni bir yöntem olarak yabancı literatürde yer alan bir yöntemdir. Bu nedenlerden ötürü bu çalışmada alternatifler MABAC yöntemi ile değerlendirilmiştir. Çalışma kapsamında Türkiye'deki tüm havalimanları (56 adet) inceleme kapsamına alınmıştır. Ancak Aydın Çıldır, Balıkesir Merkez, Çanakkale Gökçeada ve Tokat havalimanları eğitim amacıyla kullanıldığından yolcu taşımacılığı, yük taşımacılı̆̆g ve ticari uçak faaliyetlerinde bulunmadığından dolayı kapsam dışı bırakılmıştır. Dolayısıyla 52 adet havalimanı için performans değerlendirilmesi yapılmıştır. Çalışma kapsamındaki havalimanlarının kodları ve isimleri Tablo 20'de verilmiştir. 
Özdağoğlu, A., Keleş, M. K., \& Işıldak, B. (2021). Havalimanlarının Bulanık DEMATEL ve MABAC yöntemleri ile sıralanması. Ömer Halisdemir Üniversitesi İktisadi ve İdari Bilimler Fakültesi Dergisi, 14(1), 46-67.

Tablo 20: Havalimanı Kodları ve Adları

\begin{tabular}{|c|c|c|c|}
\hline Alternatif Kodu & Alternatif Adı & Alternatif Kodu & Alternatif Adı \\
\hline A1 & İstanbul Atatürk & $\mathrm{A} 27$ & $\begin{array}{l}\text { Hakkari Yüksekova } \\
\text { Selahaddin Eyyubi }\end{array}$ \\
\hline A2 & İstanbul & A28 & Hatay \\
\hline A3 & İstanbul Sabiha Gökçen & A29 & $\begin{array}{c}\text { Iğdır Şehit Bülent } \\
\text { Aydın }\end{array}$ \\
\hline A4 & Ankara Esenboğa & $\mathrm{A} 30$ & $\begin{array}{c}\text { Isparta Süleyman } \\
\text { Demirel }\end{array}$ \\
\hline A5 & İzmir Adnan Menderes & A31 & Kahramanmaraş \\
\hline A6 & Antalya & A 32 & Kars Harakani \\
\hline A7 & Alanya Gazipaşa & A33 & Kastamonu \\
\hline A8 & Muğla Dalaman & A34 & Kayseri \\
\hline A9 & Muğla Milas-Bodrum & A 35 & $\begin{array}{c}\text { Kocaeli Cengiz } \\
\text { Topel }\end{array}$ \\
\hline A 10 & Adana & A36 & Konya \\
\hline A11 & Trabzon & A 37 & Malatya \\
\hline A12 & Erzurum & A38 & Mardin \\
\hline A13 & Gaziantep & A 39 & Muş Sultan Alparslan \\
\hline A14 & Adiyaman & A40 & Kapadokya \\
\hline A15 & Ağrı Ahmed-i Hani & A41 & Ordu-Giresun \\
\hline A16 & Amasya Merzifon & A42 & Samsun Çarşamba \\
\hline A17 & Balıkesir Koca Seyit & A43 & Siirt \\
\hline A18 & Batman & A44 & Sinop \\
\hline A19 & Bingöl & A45 & Sivas Nuri Demirağ \\
\hline A20 & Bursa Yenişehir & A46 & Şanliurfa Gap \\
\hline A 21 & Çanakkale & A47 & Şırnak Şerafettin Elçi \\
\hline A22 & Denizli Çardak & A48 & $\begin{array}{c}\text { Tekirdağ Çorlu } \\
\text { Atatürk } \\
\end{array}$ \\
\hline A23 & Diyarbakır & A49 & Uşak \\
\hline A24 & Elazı̆̆ & A50 & Van Ferit Melen \\
\hline A 25 & Erzincan & A51 & Zafer \\
\hline A26 & Eskişehir Hasan Polatkan & A52 & Zonguldak Çaycuma \\
\hline
\end{tabular}

Tablo 20'de isim ve kodları verilen alternatif havalimanlarının Tablo 1'deki kriterlere göre sahip oldukları değerler Eşitlik 1'de gösterilen karar matrisini oluşturur. Karar matrisi Tablo 21'de gösterilmiştir.

Tablo 21: Karar Matrisi

\begin{tabular}{|c|c|c|c|c|}
\hline Alternatif Kodu & K1 & K2 & K3 & K4 \\
\hline A1 & 1.355 .725 & 174.816 .152 & 1.266 .054 & 8.916 .112 \\
\hline A2 & 1.639 .283 & 259.506 .216 & 1.619 .389 & 3.352 .744 \\
\hline A3 & 1.502 .875 & 225.576 .266 & 1.469 .716 & 2.343 .099 \\
\hline A4 & 659.239 & 90.833 .564 & 601.059 & 768.508 \\
\hline A5 & 532.558 & 79.428 .687 & 496.942 & 946.336 \\
\hline A6 & 1.256 .967 & 209.327 .661 & 1.209 .142 & 2.479 .516 \\
\hline A7 & 47.904 & 6.597 .035 & 44.372 & 68.567 \\
\hline A8 & 254.566 & 27.110 .408 & 167.721 & 312.208 \\
\hline A9 & 203.166 & 25.501 .358 & 166.860 & 257.815 \\
\hline A10 & 263.494 & 33.015 .943 & 211.548 & 293.596 \\
\hline
\end{tabular}


Özdağoğlu, A., Keleş, M. K., \& Işıldak, B. (2021). Havalimanlarının Bulanık DEMATEL ve MABAC yöntemleri ile sıralanması. Ömer Halisdemir Üniversitesi İktisadi ve İdari Bilimler Fakültesi Dergisi, 14(1), 46-67.

Tablo 21: Karar Matrisi

\begin{tabular}{|c|c|c|c|c|}
\hline Alternatif Kodu & K1 & K2 & K3 & K4 \\
\hline A11 & 165.300 & 24.019 .189 & 149.444 & 223.115 \\
\hline A12 & 48.064 & 6.866 .561 & 41.480 & 53.338 \\
\hline A13 & 126.280 & 16.376 .765 & 104.770 & 154.081 \\
\hline A14 & 11.650 & 1.583 .405 & 10.400 & 13.268 \\
\hline A15 & 15.152 & 2.094 .017 & 13.631 & 18.192 \\
\hline A16 & 8.762 & 1.151 .461 & 7.851 & 9.426 \\
\hline A17 & 135.362 & 2.229 .364 & 16.364 & 16.019 \\
\hline A18 & 23.496 & 3.603 .150 & 21.616 & 32.868 \\
\hline A19 & 9.672 & 1.322 .202 & 9.122 & 11.639 \\
\hline A20 & 35.646 & 1.728 .242 & 12.856 & 16.908 \\
\hline A21 & 34.572 & 845.181 & 6.407 & 6.265 \\
\hline A22 & 38.251 & 4.172 .145 & 28.537 & 41.786 \\
\hline A23 & 72.518 & 11.508 .700 & 72.052 & 89.377 \\
\hline A24 & 39.335 & 5.748 .812 & 37.220 & 53.167 \\
\hline A25 & 19.450 & 2.727 .567 & 17.613 & 21.088 \\
\hline A26 & 40.784 & 530.527 & 3.718 & 15.034 \\
\hline A 27 & 7.732 & 1.054 .985 & 7.308 & 10.893 \\
\hline A28 & 57.887 & 7.938 .831 & 54.649 & 82.726 \\
\hline A29 & 13.305 & 1.737 .845 & 11.021 & 17.863 \\
\hline A30 & 134.816 & 1.075 .360 & 6.999 & 14.132 \\
\hline A31 & 14.270 & 1.734 .030 & 12.484 & 14.750 \\
\hline A32 & 24.127 & 3.484 .349 & 21.281 & 31.913 \\
\hline A33 & 4.363 & 409.673 & 3.592 & 3.222 \\
\hline A34 & 95.841 & 14.803 .564 & 92.537 & 164.238 \\
\hline A35 & 8.029 & 374.188 & 2.270 & 3.796 \\
\hline A36 & 48.069 & 6.522 .998 & 45.686 & 62.208 \\
\hline A 37 & 34.733 & 4.822 .742 & 30.133 & 42.538 \\
\hline A38 & 23.894 & 3.767 .769 & 23.212 & 33.733 \\
\hline A39 & 16.334 & 2.555 .544 & 15.882 & 22.461 \\
\hline A40 & 69.401 & 3.039 .996 & 18.872 & 31.480 \\
\hline A41 & 50.082 & 6.893 .761 & 43.277 & 52.782 \\
\hline A42 & 90.768 & 9.955 .581 & 60.985 & 88.896 \\
\hline A43 & 2.562 & 174.067 & 1.412 & 1.766 \\
\hline A44 & 10.517 & 892.534 & 6.726 & 7.458 \\
\hline A45 & 26.413 & 3.217 .746 & 21.616 & 25.412 \\
\hline A46 & 34.635 & 4.763 .006 & 31.297 & 37.317 \\
\hline A47 & 19.201 & 2.422 .668 & 15.470 & 22.279 \\
\hline A48 & 178.462 & 476.323 & 3.304 & 7.088 \\
\hline A49 & 34.428 & 179.581 & 1.759 & 1.386 \\
\hline A50 & 94.769 & 9.456 .354 & 55.141 & 78.719 \\
\hline A51 & 5.798 & 549.823 & 4.898 & 6.529 \\
\hline A52 & 3.383 & 136.571 & 1.478 & 1.539 \\
\hline
\end{tabular}

Kaynak: Devlet Hava Meydanları İşletmesi Genel Müdürlüğü, İstatistikler, Havalimanları Karşılaştırmalı İstatistikleri, https://www.dhmi.gov.tr/sayfalar/istatistik.aspx, (Erişim Tarihi: 05.02.2020). 
Özdağoğlu, A., Keleş, M. K., \& Işıldak, B. (2021). Havalimanlarının Bulanık DEMATEL ve MABAC yöntemleri ile sıralanması. Ömer Halisdemir Üniversitesi İktisadi ve İdari Bilimler Fakültesi Dergisi, 14(1), 46-67.

Sonraki adım normalize karar matrisini oluşturmaktır. Normalize karar matrisi Tablo 22'deki gibi bulunmuştur.

Tablo 22: Normalize Karar Matrisi

\begin{tabular}{|c|c|c|c|c|}
\hline Alternatif Kodu & K1 & K2 & K3 & K4 \\
\hline $\mathrm{A} 1$ & 0,826752 & 0,673477 & 0,781619 & 1,000000 \\
\hline A2 & 1,000000 & 1,000000 & 1,000000 & 0,375935 \\
\hline A3 & 0,916658 & 0,869183 & 0,907494 & 0,262679 \\
\hline A4 & 0,401215 & 0,349682 & 0,370615 & 0,086051 \\
\hline A5 & 0,323816 & 0,305711 & 0,306265 & 0,105999 \\
\hline A6 & 0,766413 & 0,806537 & 0,746444 & 0,277982 \\
\hline A7 & 0,027703 & 0,024908 & 0,026552 & 0,007536 \\
\hline A8 & 0,153969 & 0,103998 & 0,102788 & 0,034866 \\
\hline A9 & 0,122565 & 0,097794 & 0,102256 & 0,028765 \\
\hline A 10 & 0,159424 & 0,126766 & 0,129876 & 0,032778 \\
\hline A11 & 0,099429 & 0,092079 & 0,091492 & 0,024872 \\
\hline $\mathrm{A} 12$ & 0,027801 & 0,025947 & 0,024764 & 0,005828 \\
\hline A13 & 0,075589 & 0,062614 & 0,063881 & 0,017128 \\
\hline A14 & 0,005553 & 0,005578 & 0,005555 & 0,001333 \\
\hline A15 & 0,007692 & 0,007547 & 0,007552 & 0,001885 \\
\hline A16 & 0,003788 & 0,003913 & 0,003980 & 0,000902 \\
\hline A17 & 0,081138 & 0,008069 & 0,009241 & 0,001641 \\
\hline A18 & 0,012790 & 0,013365 & 0,012487 & 0,003531 \\
\hline A19 & 0,004344 & 0,004571 & 0,004765 & 0,001150 \\
\hline A20 & 0,020214 & 0,006137 & 0,007073 & 0,001741 \\
\hline A21 & 0,019557 & 0,002732 & 0,003087 & 0,000547 \\
\hline A22 & 0,021805 & 0,015559 & 0,016765 & 0,004532 \\
\hline A23 & 0,042742 & 0,043845 & 0,043659 & 0,009870 \\
\hline A24 & 0,022467 & 0,021638 & 0,022131 & 0,005808 \\
\hline A25 & 0,010318 & 0,009990 & 0,010013 & 0,002210 \\
\hline A26 & 0,023353 & 0,001519 & 0,001425 & 0,001531 \\
\hline A27 & 0,003159 & 0,003541 & 0,003644 & 0,001066 \\
\hline A28 & 0,033802 & 0,030082 & 0,032903 & 0,009124 \\
\hline A29 & 0,006564 & 0,006174 & 0,005939 & 0,001848 \\
\hline A30 & 0,080804 & 0,003620 & 0,003453 & 0,001430 \\
\hline A31 & 0,007153 & 0,006159 & 0,006843 & 0,001499 \\
\hline A 32 & 0,013176 & 0,012907 & 0,012280 & 0,003424 \\
\hline A33 & 0,001100 & 0,001053 & 0,001347 & 0,000206 \\
\hline A34 & 0,056991 & 0,056549 & 0,056320 & 0,018268 \\
\hline A35 & 0,003340 & 0,000916 & 0,000530 & 0,000270 \\
\hline A36 & 0,027804 & 0,024623 & 0,027364 & 0,006823 \\
\hline A37 & 0,019656 & 0,018068 & 0,017751 & 0,004616 \\
\hline A38 & 0,013033 & 0,014000 & 0,013474 & 0,003628 \\
\hline A39 & 0,008414 & 0,009326 & 0,008943 & 0,002364 \\
\hline A40 & 0,040837 & 0,011194 & 0,010791 & 0,003376 \\
\hline A41 & 0,029034 & 0,026052 & 0,025875 & 0,005765 \\
\hline
\end{tabular}


Özdağoğlu, A., Keleş, M. K., \& Işıldak, B. (2021). Havalimanlarının Bulanık DEMATEL ve MABAC yöntemleri ile sıralanması. Ömer Halisdemir Üniversitesi İktisadi ve İdari Bilimler Fakültesi Dergisi, 14(1), 46-67.

Tablo 22: Normalize Karar Matrisi

\begin{tabular}{|c|c|c|c|c|}
\hline Alternatif Kodu & K1 & K2 & K3 & K4 \\
\hline A42 & 0,053892 & 0,037857 & 0,036819 & 0,009816 \\
\hline A43 & 0,000000 & 0,000145 & 0,000000 & 0,000043 \\
\hline A44 & 0,004860 & 0,002915 & 0,003284 & 0,000681 \\
\hline A45 & 0,014572 & 0,011879 & 0,012487 & 0,002695 \\
\hline A46 & 0,019596 & 0,017837 & 0,018471 & 0,004031 \\
\hline A47 & 0,010166 & 0,008814 & 0,008689 & 0,002344 \\
\hline A48 & 0,107471 & 0,001310 & 0,001169 & 0,000640 \\
\hline A49 & 0,019469 & 0,000166 & 0,000214 & 0,000000 \\
\hline A50 & 0,056336 & 0,035932 & 0,033208 & 0,008675 \\
\hline A51 & 0,001977 & 0,001593 & 0,002155 & 0,000577 \\
\hline A52 & 0,000502 & 0,000000 & 0,000041 & 0,000017 \\
\hline
\end{tabular}

Daha sonra ağırlıklı normalize karar matrisi hazırlanır. Ağırlıklı normalize karar matrisi Tablo 23 'te verilmiştir.

Tablo 23: Ağırlıklı Normalize Karar Matrisi

\begin{tabular}{|c|c|c|c|c|}
\hline Alternatif Kodu & K1 & K2 & $\mathbf{K 3}$ & K4 \\
\hline A1 & 0,398321 & 0,450442 & 0,452167 & 0,517981 \\
\hline $\mathrm{A} 2$ & 0,436097 & 0,538330 & 0,507592 & 0,356354 \\
\hline A3 & 0,417925 & 0,503119 & 0,484114 & 0,327022 \\
\hline A4 & 0,305533 & 0,363287 & 0,347856 & 0,281277 \\
\hline A5 & 0,288656 & 0,351452 & 0,331525 & 0,286443 \\
\hline A6 & 0,385164 & 0,486257 & 0,443240 & 0,330985 \\
\hline A7 & 0,224089 & 0,275870 & 0,260534 & 0,260942 \\
\hline A8 & 0,251621 & 0,297158 & 0,279883 & 0,268020 \\
\hline A9 & 0,244774 & 0,295488 & 0,279748 & 0,266440 \\
\hline $\mathrm{A} 10$ & 0,252811 & 0,303286 & 0,286758 & 0,267480 \\
\hline A11 & 0,239729 & 0,293950 & 0,277016 & 0,265432 \\
\hline A12 & 0,224111 & 0,276149 & 0,260081 & 0,260500 \\
\hline A13 & 0,234531 & 0,286019 & 0,270008 & 0,263427 \\
\hline $\mathrm{A} 14$ & 0,219259 & 0,270667 & 0,255206 & 0,259336 \\
\hline A15 & 0,219726 & 0,271196 & 0,255712 & 0,259479 \\
\hline A16 & 0,218875 & 0,270218 & 0,254806 & 0,259224 \\
\hline A17 & 0,235741 & 0,271337 & 0,256141 & 0,259416 \\
\hline A18 & 0,220838 & 0,272763 & 0,256965 & 0,259905 \\
\hline A19 & 0,218996 & 0,270395 & 0,255005 & 0,259288 \\
\hline A20 & 0,222456 & 0,270817 & 0,255591 & 0,259441 \\
\hline $\mathrm{A} 21$ & 0,222313 & 0,269900 & 0,254579 & 0,259132 \\
\hline A22 & 0,222803 & 0,273353 & 0,258051 & 0,260164 \\
\hline A23 & 0,227368 & 0,280967 & 0,264876 & 0,261547 \\
\hline A24 & 0,222948 & 0,274989 & 0,259413 & 0,260495 \\
\hline A25 & 0,220299 & 0,271854 & 0,256337 & 0,259563 \\
\hline A26 & 0,223141 & 0,269574 & 0,254157 & 0,259387 \\
\hline A27 & 0,218737 & 0,270118 & 0,254721 & 0,259267 \\
\hline
\end{tabular}


Özdağoğlu, A., Keleş, M. K., \& Işıldak, B. (2021). Havalimanlarının Bulanık DEMATEL ve MABAC yöntemleri ile sıralanması. Ömer Halisdemir Üniversitesi İktisadi ve İdari Bilimler Fakültesi Dergisi, 14(1), 46-67.

Tablo 23: Ăğırlıklı Normalize Karar Matrisi

\begin{tabular}{|c|c|c|c|c|}
\hline Alternatif Kodu & K1 & K2 & K3 & K4 \\
\hline $\mathrm{A} 28$ & 0,225419 & 0,277262 & 0,262147 & 0,261354 \\
\hline A29 & 0,219480 & 0,270827 & 0,255303 & 0,259469 \\
\hline $\mathrm{A} 30$ & 0,235668 & 0,270139 & 0,254672 & 0,259361 \\
\hline A31 & 0,219608 & 0,270823 & 0,255533 & 0,259379 \\
\hline A 32 & 0,220922 & 0,272639 & 0,256912 & 0,259877 \\
\hline A33 & 0,218289 & 0,269449 & 0,254138 & 0,259044 \\
\hline A34 & 0,230476 & 0,284386 & 0,268090 & 0,263722 \\
\hline A35 & 0,218777 & 0,269412 & 0,253930 & 0,259060 \\
\hline A36 & 0,224111 & 0,275793 & 0,260741 & 0,260757 \\
\hline A 37 & 0,222335 & 0,274028 & 0,258301 & 0,260186 \\
\hline A38 & 0,220891 & 0,272933 & 0,257215 & 0,259930 \\
\hline A39 & 0,219883 & 0,271675 & 0,256066 & 0,259603 \\
\hline A40 & 0,226953 & 0,272178 & 0,256535 & 0,259865 \\
\hline A41 & 0,224379 & 0,276177 & 0,260363 & 0,260484 \\
\hline A42 & 0,229800 & 0,279355 & 0,263140 & 0,261533 \\
\hline A43 & 0,218049 & 0,269204 & 0,253796 & 0,259001 \\
\hline A44 & 0,219109 & 0,269950 & 0,254629 & 0,259167 \\
\hline A45 & 0,221226 & 0,272363 & 0,256965 & 0,259688 \\
\hline A46 & 0,222322 & 0,273966 & 0,258484 & 0,260034 \\
\hline A47 & 0,220265 & 0,271538 & 0,256001 & 0,259597 \\
\hline A48 & 0,241483 & 0,269518 & 0,254093 & 0,259156 \\
\hline A49 & 0,222294 & 0,269210 & 0,253850 & 0,258990 \\
\hline A50 & 0,230333 & 0,278837 & 0,262224 & 0,261237 \\
\hline A51 & 0,218480 & 0,269594 & 0,254343 & 0,259140 \\
\hline A52 & 0,218158 & 0,269165 & 0,253806 & 0,258995 \\
\hline
\end{tabular}

Sonraki adım her bir kriter açısından sınır yakınlık değerlerinin hesaplanmasıdır. Sınır yakınlık alanları Tablo 24'teki gibi hesaplanmıştır.

\section{Tablo 24: Sınır Yakınlık Alanları}

\begin{tabular}{|c|c|}
\hline Kriter Kodu & $g_{j}$ \\
\hline 1 & 0,238447 \\
\hline 2 & 0,290593 \\
\hline 3 & 0,274402 \\
\hline 4 & 0,268904 \\
\hline
\end{tabular}

Daha sonra sınır yakınlık alanına uzaklıklar hesaplanır. Bu değerler Tablo 25'te verilmiştir.

Tablo 25: Sınır Yakınlık Değerleri

\begin{tabular}{|c|c|c|c|c|}
\hline Alternatif Kodu & K1 & K2 & K3 & K4 \\
\hline A1 & 0,159874 & 0,159849 & 0,177765 & 0,249077 \\
\hline A2 & 0,197651 & 0,247737 & 0,233189 & 0,087450 \\
\hline A3 & 0,179478 & 0,212526 & 0,209712 & 0,058118 \\
\hline A4 & 0,067087 & 0,072694 & 0,073454 & 0,012373 \\
\hline A5 & 0,050210 & 0,060859 & 0,057122 & 0,017539 \\
\hline
\end{tabular}


Özdağoğlu, A., Keleş, M. K., \& Işıldak, B. (2021). Havalimanlarının Bulanık DEMATEL ve MABAC yöntemleri ile sıralanması. Ömer Halisdemir Üniversitesi İktisadi ve İdari Bilimler Fakültesi Dergisi, 14(1), 46-67.

Tablo 25: Sınır Yakınlık Değerleri

\begin{tabular}{|c|c|c|c|c|}
\hline Alternatif Kodu & K1 & K2 & K3 & K4 \\
\hline A6 & 0,146718 & 0,195664 & 0,168838 & 0,062081 \\
\hline A7 & $-0,014357$ & $-0,014723$ & $-0,013868$ & $-0,007962$ \\
\hline $\mathrm{A} 8$ & 0,013175 & 0,006565 & 0,005481 & $-0,000884$ \\
\hline A9 & 0,006327 & 0,004895 & 0,005346 & $-0,002464$ \\
\hline A10 & 0,014364 & 0,012693 & 0,012356 & $-0,001424$ \\
\hline A11 & 0,001283 & 0,003357 & 0,002614 & $-0,003472$ \\
\hline A12 & $-0,014336$ & $-0,014444$ & $-0,014321$ & $-0,008404$ \\
\hline A13 & $-0,003916$ & $-0,004574$ & $-0,004394$ & $-0,005477$ \\
\hline A14 & $-0,019187$ & $-0,019926$ & $-0,019196$ & $-0,009568$ \\
\hline A 15 & $-0,018721$ & $-0,019396$ & $-0,018690$ & $-0,009425$ \\
\hline A16 & $-0,019572$ & $-0,020375$ & $-0,019596$ & $-0,009680$ \\
\hline A17 & $-0,002706$ & $-0,019256$ & $-0,018261$ & $-0,009488$ \\
\hline A18 & $-0,017609$ & $-0,017830$ & $-0,017437$ & $-0,008999$ \\
\hline A19 & $-0,019451$ & $-0,020197$ & $-0,019397$ & $-0,009616$ \\
\hline A20 & $-0,015990$ & $-0,019776$ & $-0,018811$ & $-0,009463$ \\
\hline A21 & $-0,016133$ & $-0,020692$ & $-0,019823$ & $-0,009772$ \\
\hline A 22 & $-0,015643$ & $-0,017240$ & $-0,016351$ & $-0,008740$ \\
\hline $\mathrm{A} 23$ & $-0,011078$ & $-0,009626$ & $-0,009526$ & $-0,007357$ \\
\hline A24 & $-0,015499$ & $-0,015604$ & $-0,014989$ & $-0,008409$ \\
\hline A25 & $-0,018148$ & $-0,018739$ & $-0,018065$ & $-0,009341$ \\
\hline A26 & $-0,015306$ & $-0,021019$ & $-0,020245$ & $-0,009517$ \\
\hline A 27 & $-0,019709$ & $-0,020475$ & $-0,019681$ & $-0,009637$ \\
\hline A28 & $-0,013027$ & $-0,013331$ & $-0,012256$ & $-0,007550$ \\
\hline A29 & $-0,018967$ & $-0,019766$ & $-0,019099$ & $-0,009435$ \\
\hline A30 & $-0,002779$ & $-0,020454$ & $-0,019730$ & $-0,009543$ \\
\hline A 31 & $-0,018838$ & $-0,019770$ & $-0,018870$ & $-0,009525$ \\
\hline A 32 & $-0,017525$ & $-0,017954$ & $-0,017490$ & $-0,009027$ \\
\hline A33 & $-0,020158$ & $-0,021144$ & $-0,020264$ & $-0,009860$ \\
\hline A34 & $-0,007971$ & $-0,006207$ & $-0,006312$ & $-0,005182$ \\
\hline A35 & $-0,019670$ & $-0,021181$ & $-0,020472$ & $-0,009844$ \\
\hline $\mathrm{A} 36$ & $-0,014335$ & $-0,014800$ & $-0,013661$ & $-0,008147$ \\
\hline A 37 & $-0,016112$ & $-0,016565$ & $-0,016101$ & $-0,008718$ \\
\hline A 38 & $-0,017556$ & $-0,017660$ & $-0,017187$ & $-0,008974$ \\
\hline A39 & $-0,018563$ & $-0,018918$ & $-0,018337$ & $-0,009301$ \\
\hline A40 & $-0,011493$ & $-0,018415$ & $-0,017868$ & $-0,009039$ \\
\hline A41 & $-0,014067$ & $-0,014415$ & $-0,014039$ & $-0,008420$ \\
\hline A42 & $-0,008647$ & $-0,011238$ & $-0,011262$ & $-0,007371$ \\
\hline A43 & $-0,020398$ & $-0,021389$ & $-0,020606$ & $-0,009902$ \\
\hline A44 & $-0,019338$ & $-0,020643$ & $-0,019773$ & $-0,009737$ \\
\hline A45 & $-0,017220$ & $-0,018230$ & $-0,017437$ & $-0,009216$ \\
\hline A46 & $-0,016125$ & $-0,016627$ & $-0,015919$ & $-0,008870$ \\
\hline A47 & $-0,018181$ & $-0,019055$ & $-0,018401$ & $-0,009307$ \\
\hline A48 & 0,003036 & $-0,021075$ & $-0,020310$ & $-0,009748$ \\
\hline
\end{tabular}


Özdağoğlu, A., Keleş, M. K., \& Işıldak, B. (2021). Havalimanlarının Bulanık DEMATEL ve MABAC yöntemleri ile sıralanması. Ömer Halisdemir Üniversitesi İktisadi ve İdari Bilimler Fakültesi Dergisi, 14(1), 46-67.

Tablo 25: Sınır Yakınlık Değerleri

\begin{tabular}{|c|c|c|c|c|}
\hline Alternatif Kodu & K1 & K2 & K3 & K4 \\
\hline A49 & $-0,016153$ & $-0,021383$ & $-0,020552$ & $-0,009914$ \\
\hline A50 & $-0,008114$ & $-0,011756$ & $-0,012178$ & $-0,007667$ \\
\hline A51 & $-0,019967$ & $-0,020999$ & $-0,020059$ & $-0,009764$ \\
\hline A52 & $-0,020289$ & $-0,021428$ & $-0,020596$ & $-0,009909$ \\
\hline
\end{tabular}

MABAC yönteminin son adımı alternatiflerin sınır yakınlık alanlarına uzaklıklarının toplamını hesaplamaktır. Bu değerler arasındaki en büyüğü tüm kriterler bir arada incelendiğinde en iyi alternatifi göstermektedir. Tablo 26, her bir alternatiflerin diğer bir deyişle havalimanlarının sınır yakınlık alanlarına uzaklıklarının toplamını ve bu değere göre sıralamasını göstermektedir.

Tablo 26: Toplam Uzaklık ve Sıra Değerleri

\begin{tabular}{|c|c|c|}
\hline Alternatif Kodu & $S_{i}$ & Sira \\
\hline A1 & 0,746565 & 2 \\
\hline A2 & 0,766028 & 1 \\
\hline $\mathrm{A} 3$ & 0,659834 & 3 \\
\hline A4 & 0,225608 & 5 \\
\hline A5 & 0,185730 & 6 \\
\hline A6 & 0,573300 & 4 \\
\hline A7 & $-0,050910$ & 19 \\
\hline $\mathrm{A} 8$ & 0,024337 & 8 \\
\hline A9 & 0,014104 & 9 \\
\hline A10 & 0,037989 & 7 \\
\hline A11 & 0,003781 & 10 \\
\hline A12 & $-0,051505$ & 22 \\
\hline A13 & $-0,018361$ & 11 \\
\hline A14 & $-0,067878$ & 42 \\
\hline A15 & $-0,066232$ & 38 \\
\hline A16 & $-0,069223$ & 45 \\
\hline A17 & $-0,049711$ & 18 \\
\hline A18 & $-0,061875$ & 30 \\
\hline A19 & $-0,068661$ & 44 \\
\hline A20 & $-0,064040$ & 33 \\
\hline $\mathrm{A} 21$ & $-0,066421$ & 39 \\
\hline A22 & $-0,057975$ & 28 \\
\hline $\mathrm{A} 23$ & $-0,037587$ & 13 \\
\hline A24 & $-0,054501$ & 24 \\
\hline $\mathrm{A} 25$ & $-0,064293$ & 34 \\
\hline A 26 & $-0,066087$ & 37 \\
\hline $\mathrm{A} 27$ & $-0,069503$ & 47 \\
\hline A28 & $-0,046164$ & 16 \\
\hline A29 & $-0,067267$ & 41 \\
\hline A30 & $-0,052505$ & 23 \\
\hline A 31 & $-0,067003$ & 40 \\
\hline A32 & $-0,061995$ & 31 \\
\hline
\end{tabular}


Tablo 26: Toplam Uzaklık ve Sıra Değerleri

\begin{tabular}{|c|c|c|}
\hline Alternatif Kodu & $S_{i}$ & Sira \\
\hline A33 & $-0,071427$ & 50 \\
\hline A34 & $-0,025673$ & 12 \\
\hline $\mathrm{A} 35$ & $-0,071166$ & 49 \\
\hline A36 & $-0,050944$ & 21 \\
\hline A37 & $-0,057496$ & 26 \\
\hline A38 & $-0,061376$ & 29 \\
\hline A39 & $-0,065118$ & 36 \\
\hline A40 & $-0,056815$ & 25 \\
\hline A41 & $-0,050942$ & 20 \\
\hline A42 & $-0,038518$ & 14 \\
\hline A43 & $-0,072296$ & 52 \\
\hline A44 & $-0,069491$ & 46 \\
\hline A45 & $-0,062103$ & 32 \\
\hline A46 & $-0,057540$ & 27 \\
\hline A47 & $-0,064944$ & 35 \\
\hline A48 & $-0,048097$ & 17 \\
\hline A49 & $-0,068001$ & 43 \\
\hline A50 & $-0,039715$ & 15 \\
\hline A51 & $-0,070789$ & 48 \\
\hline A52 & $-0,072221$ & 51 \\
\hline
\end{tabular}

\section{SONUC VE DEĞERLENDİRME}

Havacılık sektörü, sahip olduğu avantajlar, hız ve konforun ön plânda olması sebebiyle hızlı bir şekilde gelișim göstermektedir. Bunun yanı sıra büyük mesafeler arası sağladığ kolaylıklar nedeniyle küreselleșen dünyada etkili ve çok önemli bir ulaşım alternatifi haline gelmiştir. Bu hızlı gelişim ve ülkeler arası etkileşimin de artmasına paralel olarak havayolu ulaşımına talep artmış, dolayısıyla bu durum havalimanlarının da çok hızlı bir büyüme ve gelişim göstermesine yol açmıştır.

Havalimanlarında, yolculara havalimanında geçirdikleri süre içerisinde uçağa bindikleri zamana kadar çok sayıda hizmet sunulmaktadır. Havalimanı yönetimleri, yolculara sundukları hizmetten duyulan memnuniyet durumu ve havalimanı ile ilgili görüşlerini araştırmalıdırlar. Çünkü yolcuların hizmetlerden algıladıkları memnuniyet durumu, havalimanının hizmet kalitesi, o havalimanının yolcular tarafından tercih edilmesini doğrudan etkilemektedir. Dolayısıyla havalimanı yönetimi, yolculara sunulan hizmetlerin müşteri memnuniyetini etkileme durumuna göre gerekli plân ve stratejilerin yapmalı, havalimanlarını kullanan insanların taleplerini ve ihtiyaçlarını göz önüne alarak önlemler almalıdırlar.

Proje olarak havalimanları bulundukları bölgelerin sosyo-ekonomik faaliyetlerine doğrudan tesir ederken ciddi sermayelerin bağlandığı ve alternatif kullanım olanağı olmayan sabit yatırım varlıklarıdır. Yatırım plânları ülke kaynaklarının doğru kullanılması açısından önemli bir yere sahip olduğu için havalimanlarının performansı ve etkin kullanılmasını gerektirmektedir.

Bu çalışmada DHMI'nin 2019 havalimanlarına ilişkin verileri baz alınarak Türkiye'de faaliyet gösteren 52 adet havalimanının performansları değerlendirilmeye çalışılmıştır. Değerlendirmede ÇKKV yöntemlerinden Bulanık DEMATEL ve MABAC kullanılmıştır. Bulanık DEMATEL ile 4 adet kriterin ağırlı̆̆ı belirlenmiştir. Söz konusu kriterler; havalimanına inen ve kalkan "toplam uçak sayısı", havalimanını kullanarak seyahat eden "yolcu sayısı", havalimanını kullanan "ticari uçak sayısı", havalimanında işlem gören "yük miktarı" kriterleridir. Yapılan değerlendirmede havalimanını kullanarak seyahat eden "yolcu sayısı" ağırlığı en yüksek olan kriter 
olarak çıkmış, havalimanına inen ve kalkan "toplam uçak sayısı" ise ağırlığı en düşük kriter olmuştur.

Havalimanlarının performans sıralaması, MABAC yöntemi ile yapılmıştır. Türkiye'de faaliyet gösteren 52 adet havalimanı MABAC yöntemiyle sıralanmıştır. Yapılan sıralamada ilk 3 sırayı İstanbul'da faaliyet gösteren havalimanları almıştır. İlk sırada yeni açılan İstanbul Havalimanı yer alırken ikinci sırayı 2019'da kapanan Atatürk Havalimanı almıştır. Üçüncü sırada ise Sabiha Gökçen Havalimanı bulunmaktadır. Aynı bölgeye hitap eden ve özellikle birbirlerine yakın bir biçimde konumlandırılmış havalimanları ise öncelikle direkt yolcu trafiğinde rekabet etmektedir. Bu tür rekabetin bir örneği Devlet Hava Meydanları İşletmesi Genel Müdürlüğ̈̈ (DHMİ)'nün 2019 yılı verilerine göre ülkemizde, İstanbul'da yaşanmaktadır. Kentin bir yakasında, daha önce Atatürk Havalimanı şimdi İstanbul Yeni Havalimanı, diğer yakasında ise Sabiha Gökçen Havalimanı hizmet veriyor. Yılın ilk üç ayı Atatürk Havalimanı faal durumdayken, yeni havalimanına taşınmanın ardından bu üstünlüğ̈ünü kaybetti. İstanbul Yeni Havalimanı'nda dış hat seferi nokta sayısı fazla iken, Sabiha Gökçen Havalimanı'nın da iç hat nokta sayısının fazla oluşu ve bu iki havalimanının bulunduğu konumlar, yolcuların tercihinde önemli bir role sahiptir. Önümüzdeki y1llarda İstanbul Yeni Havalimanı - Sabiha Gökçen Havalimanı rekabetinin nasıl şekilleneceğinde, hâlihazırda devam eden altyapı çalışmaları ve uçuş nokta çeşitliliği belirleyici olacaktır. Bunun yanında turizmin canlanmasıyla birlikte hızlı bir yükselișe geçen Antalya Havalimanı'nın potansiyeli de göz ardı edilmemelidir. Son siralarda ise; Siirt, Zonguldak Çaycuma ve Kastamonu havalimanları bulunmaktadır. Konumları gereği şehir merkezlerine uzak oluşları, sefer sayılarının az ve uçuş saatlerinin düzensiz olması yolcuların tercihini etkilemektedir. Bunun için de yolcuları teşvik edecek kampanyaların yapılması ve uçuş şartlarının iyileştirilmesi havalimanlarının performansını doğrudan arttıracaktır.

Bundan sonra yapılacak çalışmalarda, havalimanı performanslarının ölçümünde farklı ÇKKV yöntemleri kullanılabilir. 
Etik Beyanı

: Bu çalışmanın tüm hazırlanma süreçlerinde etik kurallara uyulduğunu yazarlar beyan eder. Aksi bir durumun tespiti halinde ÖḦ̈IİBF Dergisinin hiçbir sorumluluğu olmayıp, tüm sorumluluk çalışmanın yazar(lar)ına aittir. Veriler 2020 yılı öncesi toplandığından etik kurul kararı gerekmemektedir.

Yazar Katkıları

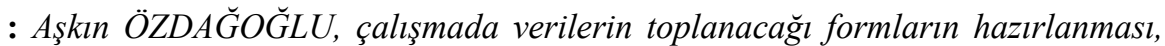
çalışmanın kurgusunun yapılması, çalışmada kullanılan yöntemlerin algoritmasının anlatılması, çalışmada kullanılan yöntemlere göre verilerin analizinin yapılması konularında katkı sağlamıştır. Murat Kemal KELEŞ, çalışma konusunun belirlenmesi, giriş ve sonuç bölümü, literatür araştırması, kısımlarında katkı sağlamıştır. Barış IŞILDAK çalışma konusuna, giriş ve sonuç kısmına teknik anlamda destek olmuş, çalışma konusunun belirlenmesi, verilerin toplanması konularında katkı sağlamıştır. 1. yazarın katkı oranı:\%40, 2. yazarın katkı oranı: \%30, 3. yazarın katkı oranı: \%30

\section{Çıkar Beyanı : : Yazarlar arasında çıkar çatışması yoktur. \\ Teşekkür : Makalenin yayın sürecindeki katkılarından dolayı ÖHÜIİBF Dergisi Editör Kurulu'na ve hakemlere teşekkür ederiz.}

Ethics Statement : As authors, we declare that in all the processes of the article, The Journal ÖHÜIIBF acts in accordance with the principles of research and publication ethics. If otherwise determined, we will inform you that all responsibility belongs to the authors. Since data is collected before 2020, no ethics committee decision is required.

Author Contributions : Aşkın ÖZDA $\breve{G} O \breve{G} L U$ has contributed to the preparation of the forms in which the data was collected in the study, the editing of the study, the explanation of the algorithm of the methods used in the study, and the analysis of the data according to the methods used in the study. Murat Kemal KELEŞ contributed to the determination of the subject of the study, the introduction and conclusion part, the literature research. Barıs ISSILDAK provided technical support for the study subject, introduction and conclusion, and contributed to the determination of the study subject and the collection of data. 1st author's contribution rate: $\%$ 40, 2nd author's contribution rate: \% 30, 3rd author's contribution rate: \% 30

Conflict of Interest : There is no conflict of interest among the authors
$\begin{aligned} & \text { Acknowledgement } \quad: \text { We would like to thank the Editorial Board of the ÖHÜIIBF Journal and the } \\ & \text { referees for their contribution to the process of publication of the article. }\end{aligned}$

\section{KAYNAKÇA}

Ahn, Y. H., \& Min, H. (2014). Evaluating the multi-period operating efficiency of international airports using data envelopment analysis and the Malmquist productivity index. Journal of Air Transport Management, 39, 12-22. https://doi.org/10.1016/j.jairtraman.2014.03.005.

Albayrak, Ö., \& Erkayman, B. (2018). Bulanık DEMATEL ve EDAS yöntemleri kullanılarak sporcular için ak1llı bileklik seçimi. Ergonomi, 1(2), 92-102.

Altan, Ş., \& Karaş Aydın, E. (2015). Bulanık DEMATEL ve bulanık TOPSIS yöntemleri ile üçüncü parti lojistik firma seçimi için bütünleşik bir model yaklaşımı. Süleyman Demirel Üniversitesi İktisadi ve İdari Bilimler Fakültesi Dergisi, 20(3), 99-119.

Ar, İ. M. (2012). Türkiye'deki havalimanlarının etkinliklerindeki değişimin incelenmesi: 2007-2011 dönemi için malmquist-tfv endeksi uygulaması. Atatürk Üniversitesi İktisadi ve İdari Bilimler Dergisi, 26(3-4), 143-160.

Avcı, T., \& Aktaş, M. (2015). Türkiye'de faaliyet gösteren havalimanlarının performanslarının değerlendirilmesi. Uluslararası Alanya İşletme Fakültesi Dergisi, 7(3), 66-77.

Ayçin, E., \& Çakın, E. (2019). Ülkelerin inovasyon performanslarının ölçümünde ENTROPİ ve MABAC çok kriterli karar verme yöntemlerinin bütünleşik olarak kullanılması. Akdeniz Üniversitesi İktisadi ve İdari Bilimler Fakültesi Dergisi, 19(2), 326-351. https://doi.org/10.25294/auiibfd.649275.

Bakır, M. (2019). SWARA ve MABAC yöntemleri ile havayolu işletmelerinde ewom'a dayalı memnuniyet düzeyinin analizi. İzmir Iktisat Dergisi, 34(1), 51-66. Doi: 10.24988/ije.2019341787.

Chang, B., Chang, C.W., \& Wu, C. H. (2011). Fuzzy DEMATEL method for developing supplier selection $\begin{array}{llll}\text { criteria. Expert } \text { Systems } & \text { 1850-1858. }\end{array}$ http://doi.org/10.1016/j.eswa.2010.07.114. 
Özdağoğlu, A., Keleş, M. K., \& Işıldak, B. (2021). Havalimanlarının Bulanık DEMATEL ve MABAC yöntemleri ile sıralanması. Ömer Halisdemir Üniversitesi İktisadi ve İdari Bilimler Fakültesi Dergisi, 14(1), 46-67.

Dao, P. (2016). Performance evaluation based on financial ratios case: finnair and scandinavian airlines. (Degree Thesis, International Business, Arcada). Retrieved from https:/www.theseus.fi/bitstream/handle/10024/112381/Thesis\%20.pdf?sequence=1.

Dash, M. (2019). Comparison of performance of indian aviation service providers using multi-criteria decision models. Asian Journal of Pure and Applied Mathematics, 1(1), 16-26.

Devlet Hava Meydanları İşletmesi Genel Müdürlüğü, İstatistikler, Havalimanları Karşılaştırmalı İstatistikleri, https:/www.dhmi.gov.tr/sayfalar/istatistik.aspx, (Erişim Tarihi: 05.02.2020).

Devlet Hava Meydanları İşletmesi Genel Müdürlüğü, İstatistikler, Havalimanı İstatistikleri Metaveri Dosyası, https://www.dhmi.gov.tr/sayfalar/istatistik.aspx, (Erişim Tarihi: 29.02.2020).

Elgün, A., Babacan, E., Kozak, M., \& Babat, D. (2013). Yeni tüketim mekânları olarak havalimanı terminalleri. Anatolia: Turizm Araştırmaları Dergisi, 24(1), 70-82.

Ersin, İ., Dinçer, H., \& Yüksel, S. (2019). Yerel yönetimlerde yatırım kriterlerinin belirlenmesi: bulanık DEMATEL yöntemiyle bir analiz. Yönetim ve Ekonomi: Celal Bayar Üniversitesi İktisadi ve İdari Bilimler Fakültesi Dergisi, 26(2), 477-493. https://doi.org/10.18657/yonveek.496291.

Gigovic, L., Pamucar, D., Bozanic, D., \& Ljubojevic, S. (2017). Application of the GIS-DANP-MABAC multicriteria model forselecting the location of wind farms: a case study of vojvodina. Serbia. Renewable Energy. 103, 501-521. http://dx.doi.org/10.1016/j.renene.2016.11.057.

Gökdalay, M. H., \& Evren, G. (2009). Havaalanlarının performans analizinde bulanık çok ölçütlü karar verme yaklaşımı. ITÜ̈DERGISII/d, 8(6), 157-168.

Işıldak, B. (2017). Havalimanı hizmetini ve müşteri memnuniyetini belirlemeye yönelik bir araştırma. (Yüksek Lisans Tezi). Süleyman Demirel Üniversitesi Sosyal Bilimler Enstitüsü, Isparta.

Işıldak, B., \& Tunca, M. Z. (2018). Havalimanı hizmetlerinde müşteri memnuniyetini etkileyen faktörler üzerine bir araştırma. Süleyman Demirel Üniversitesi İktisadi ve İdari Bilimler Fakültesi Dergisi, 23(1), 241-255.

Koç, E. (2019). Uluslararası tedarikçi seçim probleminde bulanık DEMATEL yönteminin kullanımı. Bingöl Üniversitesi Sosyal Bilimler Enstitüsü Dergisi (BUSBED), 9(17), 339-355.

Ling, F. I., Lin, K., \& Lu, J. L. (2005). Difference in service quality of cross-strait airlines and its effect on passengers' preferences. Journal of the Eastern Asia Society for Transportation Studies, 6, 798-813. https://doi.org/10.11175/easts.6.798.

Merkert, R., \& Assaf, A. G. (2015). Using dea models to jointly estimate service quality perception and profitability-evidence from international airports. Transportation Research Part A: Policy and Practice, 75, 42-50. http://dx.doi.org/10.1016/j.tra.2015.03.008.

Organ, A. (2013). Bulanık DEMATEL yöntemiyle makine seçimini etkileyen kriterlerin değerlendirilmesi. Çukurova Üniversitesi Sosyal Bilimler Enstitüsü Dergisi, 22(1), 157-172.

Pamučar, D., \& Ćirović, G. (2015). The selection of transport and handling resources in logistics centers using multi-attributive border approximation area comparison (MABAC). Expert Systems with Applications, 42(6), 3016-3028. https://doi.org/10.1016/j.eswa.2014.11.057.

Petrović, I., \& Kankaraš, M. (2018). DEMATEL-AHP multi-criteria decision-making model for the selection and evaluation of criteria for selecting an aircraft for the protection of air traffic. Decision Making: Applications in Management and Engineering, 1(2), 93-110.

Pishdar, M., Ghasemzadeh, F., \& Antuchevičienè, J. (2019). A mixed interval type-2 fuzzy BEST-WORST MACBETH approach to choose hub airport in developing countries: case of Iranian passenger airports. Transport, 34(6), 639-651.

Shyr, O. F., \& Kuo, Y. P. (2008). Applying TOPSIS and cooperative game theory in airline merging and coalition decisions. Journal of Marine Science and Technology, 16(1), 8-18.

Ulutaş, A. (2019). ENTROPİ ve MABAC yöntemleri ile personel seçimi. OPUS Uluslararasi Toplum Araştırmaları Dergisi, 13(19) , 1552-1573. DOI: 10.26466/opus.580456.

Vesković, S., Stević, Ž., Stojić, G., Vasiljević, M., \& Milinković, S. (2018). Evaluation of the railway management model by using a new integrated model DELPHI-SWARA-MABAC. Decision Making: Applications in Management and Engineering, 1(2), 34-50. DOI: https:// 10.31181/dmame1802034v.

Yapraklı, Ş., \& Sağlık, E. (2010). Hizmet işletmelerinde rekabet aracı olarak hizmet kalitesi ve ilişki kalitesi: konaklama işletmelerinde bir uygulama. Öneri Dergisi, 9(34), 71-85.

Yu, S. M., Wang, J., \& Wang, J. Q. (2017). An interval type-2 fuzzy likelihood-based MABAC approach and its application in selecting hotels on a tourism website. International Journal of Fuzzy Systems, 19(1), 47-61. 